Zeszyty Naukowe Szkoły Głównej Gospodarstwa Wiejskiego w Warszawie Problemy Rolnictwa Światowego tom 17 (XXXII), zeszyt 2, 2017: 81-92

DOI: $10.22630 /$ PRS.2017.17.2.28

Zuzanna Jarosz ${ }^{1}$

Instytut Uprawy Nawożenia i Gleboznawstwa - Państwowy Instytut Badawczy

w Puławach

\title{
Potencjał energetyczny biomasy roślinnej i możliwości wykorzystania do celów energetycznych
}

\section{Energy Potential of Agricultural Crops Biomass and Their Use for Energy Purposes}

\begin{abstract}
Synopsis. Zapewnienie bezpieczeństwa energetycznego, uniezależnienie się od paliw kopalnych oraz ograniczenie emisji gazów cieplarnianych skłania do wykorzystywania odnawialnych źródeł energii. Celem badań jest ocena potencjału energetycznego biomasy roślinnej z produkcji rolnej i wskazanie możliwości jej wykorzystania do produkcji energii elektrycznej i ciepła. Do badań wykorzystano dane z Powszechnego Spisu Rolnego 2010. Na podstawie szczegółowej analizy zmian zachodzących w produkcji rolniczej w latach 2010-2015 dokonano aktualizacji danych. Przyjęto założenie, że zmiany w gminach zachodziły w taki sam sposób jak w województwach. Potencjał energetyczny biomasy roślinnej oszacowano uwzględniając: nadwyżki słomy, siana i plantacje roślin energetycznych. Z przeprowadzonych badań wynika, że Polska dysponuje energetycznym potencjałem biomasy roślinnej kształtującym się na poziomie 305,8 tys. TJ rocznie, który może być wykorzystany do celów energetycznych bez zagrożenia dla produkcji żywności.
\end{abstract}

Słowa kluczowe: biomasa, słoma, siano, rośliny energetyczne, potencjał energetyczny

\begin{abstract}
The need to ensure energy security, decouple energy production from fossil fuels and reduce greenhouse gas emission are driving the use of renewable energy sources. The purpose of the study is to assess the energy potential of agricultural crops biomass and to indicate its potential for electricity and heat production. The data from the Agricultural Census 2010 were used for analyses. On the basis of the detailed analysis of the changes in agricultural production in the years 2010-2015 the data has been updated. Is was assumed that the changes in communes were similar to those in voivodships. The energy potential of the crop biomass was estimated taking into account surpluses of straw, hay and perennial energy crops biomass. The study shows that energy potential of the biomass without jeopardizing food production amounts at 305,8 thousand TJ per year.
\end{abstract}

Key words: biomass, straw, hay, perennial energy crops, energy potential

\section{Wprowadzenie}

Współczesne rolnictwo stoi przed wieloma trudnymi wyzwaniami. $\mathrm{Z}$ jednej strony istnieje potrzeba poszukiwania nowoczesnych rozwiązań technologicznych, które gwarantowałyby zabezpieczenie popytu na żywność, z drugiej zaś istnieje konieczność ograniczania emisji gazów cieplarnianych odpowiedzialnych za proces ocieplenia i przyczyniających się do zmian klimatu.

\footnotetext{
${ }^{1}$ dr, Zakład Biogospodarki i Analiz Systemowych IUNG-PIB, ul. Czartoryskich 8, 24-100 Puławy, e-mail: zjarosz@iung.pulawy.pl
} 
Przyjęty przez Parlament Europejski w grudniu 2008 roku pakiet energetycznoklimatyczny (znany także jako pakiet „3x20” lub ,20-20-20”) określił w perspektywie 2020 r. podstawowe cele w zakresie polityki energetycznej. Dokumenty wchodzące w skład pakietu skupiały się na trzech kluczowych zagadnieniach:

- redukcji o 20\% emisji gazów cieplarnianych w stosunku do poziomu emisji z 1990 roku,

- zwiększeniu udziału zużycia energii pochodzącej z odnawialnych źródeł energii do 20\% i o co najmniej 10\% udziału biopaliw w ogólnym zużyciu paliw transportowych,

- zwiększeniu o $20 \%$ efektywności energetycznej.

Cel 20\% udziału energii ze źródeł odnawialnych (OZE) w 2020 r. został przełożony na indywidualne cele poszczególnych państw członkowskich. Udziały te są zróżnicowane i kształtują się od 10\% dla Malty do 49\% dla Szwecji (Energia..., 2016). Dla Polski udział energii z OZE ma wynosić $15 \%$.

Polska, funkcjonując w strukturach europejskich, powinna prowadzić politykę zgodną ze strategią Unii Europejskiej, której podstawą jest stały wzrost udziału energii pozyskiwanej ze źródeł odnawialnych i dążenie do ograniczania emisji gazów cieplarnianych. W grudniu 2010 roku Rada Ministrów przyjęła "Krajowy plan działania w zakresie energii ze źródeł odnawialnych", w którym stwierdzono, że rozwój wykorzystania OZE umożliwi zaspokojenie rosnącego zapotrzebowania na energię oraz pozwoli na uniezależnienie się od dostaw energii z importu. Większe wykorzystanie OZE umożliwi także zwiększenie dywersyfikacji dostaw energii, powstanie nowych miejsc pracy, promowanie rozwoju regionalnego oraz stworzenie warunków do rozwoju energetyki rozproszonej opartej na lokalnych źródłach.

Energetyka odnawialna bazuje na zasobach biomasy. Udział biomasy w UE w bilansie energii finalnej wynosi około $60 \%$, a w Polsce ponad $90 \%$. Według dyrektywy 2009/28/WE (Dyrektywa..., 2009) biomasa oznacza ulegającą biodegradacji część produktów, odpadów lub pozostałości pochodzenia biologicznego z rolnictwa, leśnictwa i związanych działów przemysłu, w tym rybołówstwa i akwakultury, a także ulegającą biodegradacji część odpadów przemysłowych i miejskich. Każdy rodzaj biomasy może być produkowany na cele energetyczne, pod warunkiem zapewnienia bezpieczeństwa żywnościowego. Dlatego coraz większą uwagę przywiązuje się do wykorzystania na cele energetyczne biomasy ubocznej.

Celem opracowania jest oszacowanie potencjału energetycznego biomasy z upraw rolnych i wskazanie możliwości jej wykorzystania do produkcji energii elektrycznej i ciepła. Skupiono się na niemających wpływu na poziom produkcji żywności plonach ubocznych z produkcji roślinnej (słoma, siano) oraz biomasy produkowanej bezpośrednio na cele energetyczne (wieloletnie plantacje roślin energetycznych).

\section{Dane i metody}

Podstawą do przeprowadzenia analiz były dane statystyczne GUS pochodzące z Państwowego Spisu Rolnego z 2010 roku dla 2479 gmin miejskich, wiejskich i miejskowiejskich (PSR..., 2010). Analizowane dane obejmowały: powierzchnie zasiewów poszczególnych gatunków zbóż i trwałych użytków zielonych, stan pogłowia zwierząt gospodarskich w podziale na gatunki i grupy użytkowe oraz powierzchnie jakości gleb 
według rodzajów. Zdezagregowane dane o produkcji zbóż pochodziły z modelu RENEW (RENEW, 2008).

Jak wskazuje Gradziuk (2015), o możliwości alternatywnego wykorzystania nadwyżki produktów ubocznych z produkcji roślinnej decyduje ich wolumen i stabilność produkcji. W latach 2010-2015 nastąpiły istotne zmiany w produkcji rolniczej (w powierzchni zasiewów i wielkości plonów poszczególnych gatunków zbóż, roślin oleistych oraz trwałych użytków zielonych, zmiany pogłowia zwierząt gospodarskich). Dało to asumpt do przeprowadzenia szczegółowej analizy zaistniałych zmian w latach 2010-2015 w skali województw. Następnie, przyjmując założenie, że zmiany w poszczególnych gminach zachodziły w taki sam sposób jak w województwach, dokonano aktualizacji danych pochodzących z PSR 2010. Na podstawie zgromadzonych danych oraz wiedzy o proporcjach między plonem głównym i ubocznym oszacowano całkowite zasoby słomy w przekroju gmin. Uwzględnione w obliczeniach współczynniki plonu słomy do plonu ziarna różniły się wielkością w zależności od gatunku rośliny i poziomu uzyskiwanych plonów (Harasim, 2011). W celu określenia realnych zasobów słomy na cele energetyczne należało uwzględnić jej zapotrzebowanie do produkcji rolniczej (na ściółkę i paszę dla zwierząt) oraz na przyoranie. Do obliczenia ilości słomy niezbędnej na paszę i ściółkę wykorzystano normatywy rocznego zapotrzebowania poszczególnych gatunków zwierząt na słomę zużywaną na wymienione cele oraz liczebność pogłowia zwierząt gospodarskich (Grzybek, 2002, Gradziuk, 2002). W szacunkach potencjału energetycznego uwzględniono także zużycie słomy niezbędnej do reprodukcji substancji organicznej w glebie (słoma na przyoranie). W obliczeniach wykorzystano współczynniki reprodukcji (odtwarzania) i degradacji (rozkładu) glebowej substancji organicznej. Wielkość tych współczynników zależy od uprawianej rośliny i rodzaju gleby oraz rodzaju stosowanych nawozów naturalnych i mineralnych (Harasim, 2011). Do oszacowania nadwyżki słomy możliwej do wykorzystania do celów energetycznych zastosowano formułę (Ludwicka, Grzybek, 2010):

$$
\mathrm{N}=\mathrm{P}-\left(\mathrm{Z}_{\mathrm{s}}+\mathrm{Z}_{\mathrm{p}}+\mathrm{Z}_{\mathrm{n}}\right)
$$

gdzie: $\mathrm{N}$ - nadwyżka słomy do wykorzystania poza rolnictwem $(\mathrm{t}), \mathrm{P}$ - wielkość produkcji słomy zbóż (t), $Z_{s}$ - zapotrzebowanie słomy na ściółkę $(\mathrm{t}), \mathrm{Z}_{\mathrm{p}}$ - zapotrzebowanie na słomę przeznaczoną na paszę $(\mathrm{t}), \mathrm{Z}_{\mathrm{n}}$ - zapotrzebowanie na słomę przeznaczoną na przyoranie $(\mathrm{t})$.

Oszacowaną nadwyżkę słomy przeliczono na energię, przyjmując że 1 tona słomy o wilgotności $15 \%$ ma wartość opałową 13,1 GJ.

Znaczący zasób biomasy stanowi siano uzyskiwane $\mathrm{z}$ trwałych użytków zielonych (TUZ). W szacunkach potencjału energetycznego uwzględniono ilość siana związaną z chowem przeżuwaczy. Przyjęto, że dzienne zapotrzebowanie siana na dużą jednostkę przeliczeniową (DJP) wynosi 20kg (Winnicki i in., 2012). Oszacowaną nadwyżkę siana przeliczono na energię, przyjmując że 1 tona siana o wilgotności 15\% ma wartość opałową 13,4 GJ. Do obliczeń wykorzystano formułę:

$$
\mathrm{N}_{\mathrm{si}}=(\mathrm{Pow} \cdot \mathrm{Y})-(\mathrm{DJP} \cdot \mathrm{Sk})
$$

gdzie: $\mathrm{N}_{\mathrm{si}}$ - nadwyżka siana $(\mathrm{t}), \mathrm{Y}$ - średni plon siana $\mathrm{w}$ regionie $\left(\mathrm{t} \mathrm{ha}^{-1}\right)$, Pow powierzchnia TUZ (ha), DJP - ilość jednostek przeliczeniowych na sztukę $i$ rodzaju inwentarza (przeżuwacze), Sk - ilość siana przeznaczona na DJP. 
Ważną rolę wśród potencjalnych zasobów biomasy odgrywają także celowe uprawy energetyczne (wierzba, miskant, ślazowiec pensylwański, topola). Analizę potencjału z plantacji energetycznych przeprowadzono w przekroju województw na podstawie danych PSR 2010 uzupełnionych o informacje pozyskane z Agencji Restrukturyzacji i Modernizacji Rolnictwa (ARiMR). Stopień szczegółowości limitowany był dostępnością danych. Potencjał roślin energetycznych można przedstawić równaniem:

$$
\mathrm{Pw}=[\mathrm{Pe}+(\mathrm{Pg} \cdot \mathrm{we})] \cdot \mathrm{Ye}
$$

gdzie: $\mathrm{Pw}$ - potencjał wieloletnich roślin energetycznych $\left(\mathrm{t} \operatorname{rok}^{-1}\right), \mathrm{Pe}-$ powierzchnia istniejących plantacji wieloletnich roślin energetycznych (ha), $\mathrm{Pg}$ - powierzchnia gruntów przydatnych do uprawy roślin energetycznych (ha), we - współczynnik wykorzystania gruntów pod uprawę wieloletnich roślin energetycznych (\%), Ye - przeciętny plon wieloletnich roślin energetycznych $\left(\mathrm{t} \mathrm{ha}^{-1}\right)$.

Do uprawy roślin energetycznych najbardziej odpowiednie są tereny, na których znajdują się gleby zaliczane do 5, 6, 8, 9 oraz $2 \mathrm{z}$ i $3 z$ kompleksu przydatności rolniczej. Współczynnik wykorzystania tych gruntów pod uprawę roślin energetycznych przyjęto na poziomie 10\%. Jak wskazuje Kuś i Faber (2007), owe 10\% jest bezpieczną granicą eliminującą konkurencję między produkcją surowca a produkcją na cele żywnościowe.

\section{Wyniki badań}

Wykorzystanie biomasy do celów energetycznych zależy od możliwości produkcyjnych rolnictwa. Najbardziej dostępnym źródłem biomasy ubocznej z produkcji roślinnej jest słoma. Wielkość zasobów słomy limitowana jest powierzchnią zasiewów zbóż i roślin oleistych oraz wydajnością z hektara. Według PSR w 2010 r. powierzchnia zasiewów zbóż wynosiła 7 186,7 tys. ha, a rzepaku i rzepiku 946,1 tys. ha, co przy średnich plonach wynoszących odpowiednio 34,9 oraz $23,1 \mathrm{dt}$ z ha pozwoliło na zebranie ponad 32 mln ton słomy. W 2015 r. powierzchnia zasiewów zbóż zmniejszyła się do 6749,7 tys. ha, a rzepaku i rzepiku nieznacznie wzrosła do 947,1 tys. ha w porównaniu do $2010 \mathrm{r}$. Wzrosły natomiast średnie plony zbóż, do 37,3 dt z ha, a rzepaku i rzepiku do 28,5 dt z ha. Znaczące zmiany zaobserwowano w powierzchni zasiewów i plonowaniu kukurydzy, które w $2010 \mathrm{r}$. wynosiły odpowiednio 334,2 tys. ha i 59,7 dt z ha. W 2015 r. zaś uprawa kukurydzy zajmowała 670,3 tys. ha powierzchni i plonowała na poziomie $47,1 \mathrm{dt} z$ ha. Stwierdzone zmiany wpłynęły na podwyższenie zbiorów słomy w 2015 r., które wyniosło 32,8 mln ton. Największy udział w zasobach miała słoma pszenicy ozimej, pszenżyta ozimego i żyta (Jarosz, 2016). Jak wskazuje Harasim (2011) słomy te są twarde i dlatego powinny być przeznaczane na ściółkę. Jedynie słoma żytnia z ziarnem zbóż stanowi odpowiednią paszę dla koni. Natomiast słoma rzepakowa, ze względu na zawartość większej ilości azotu, doskonale nadaje się do przyorywania.

Podstawowym kierunkiem wykorzystania słomy jest jej zagospodarowanie w rolnictwie jako pasza i ściółka dla zwierząt oraz substrat zwiększający reprodukcję materii organicznej w glebie (Scarlat i in., 2010). Jednak zmiany w produkcji rolniczej w Polsce (zmniejszenie pogłowia zwierząt, powstawanie większej liczby gospodarstw bezinwentarzowych) wpłynęły na uzyskiwanie znacznych nadwyżek słomy. 
Zapotrzebowanie słomy na paszę i ściółkę zależy od stanu pogłowia zwierząt gospodarskich i okresu żywienia oraz od sposobu ich utrzymania (rodzaju pomieszczeń inwentarskich). Przeprowadzone obliczenia wykazały, że na potrzeby utrzymania zwierząt gospodarskich należy przeznaczyć 11332 tys. t, co stanowiło 34,5\%. Zarówno zmiany w produkcji zwierzęcej powodujące niedobór obornika w gospodarstwach, jak i zmiany w strukturze zasiewów powodujące wzrost udziału roślin o niekorzystnych właściwościach oddziaływania na gleby zwiększają popyt na słomę niezbędną na przyoranie. Oszacowana wielość słomy pozostawianej na polu i wykorzystanej jako nawóz wyniosła około 4698,7 tys. ton, tj. 14,3\%. Odliczając zapotrzebowanie słomy na cele rolnicze, do zagospodarowania pozostało 16789 tys. ton nadwyżki słomy. Uzyskana dla 2015 r. wielkość nadwyżki słomy jest zbliżona do wielkości prognozowanej nadwyżki wyznaczonej na podstawie modelu przyczynowo -skutkowego przez Gradziuka (2015).Ten znaczący dla energetyki rodzaj biomasy pochodzenia roślinnego może dostarczyć 219934 TJ energii. Przyjmując, że średnia wartość opałowa węgla wynosi $24 \mathrm{MJ} \mathrm{kg}^{-1}$, oszacowana biomasa mogłaby zastapić ponad $9,16 \mathrm{mln}$. ton weggla. Potencjał energetyczny słomy jest zróżnicowany regionalnie (rys. 1). Największe zasoby słomy energetycznej występują w gminach skupionych w zachodniej, północnej i częściowo wschodniej części kraju. Największym potencjałem charakteryzują się województwa: wielkopolskie - 30 415,3 TJ/ rok, dolnośląskie - 27 791,0 TJ/rok i lubelskie - 23 191,2 TJ/rok (rys. 2). Nieco mniejszy potencjał energetyczny zasobów słomy stwierdzono w województwach: zachodniopomorskim - $20800,5 \mathrm{TJ} /$ rok, kujawsko-pomorskim - $19441,0 \mathrm{TJ} / \mathrm{rok}$ i opolskim - $16306,6 \mathrm{TJ} /$ rok.

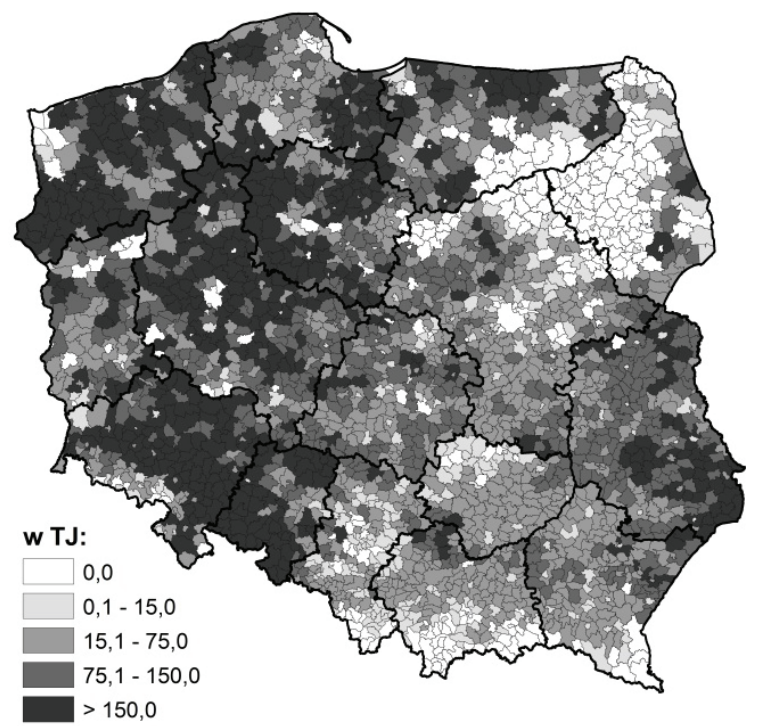

Rys. 1. Potencjał energetyczny słomy

Fig. 1. Energy potential of straw

Źródło: opracowanie własne. 


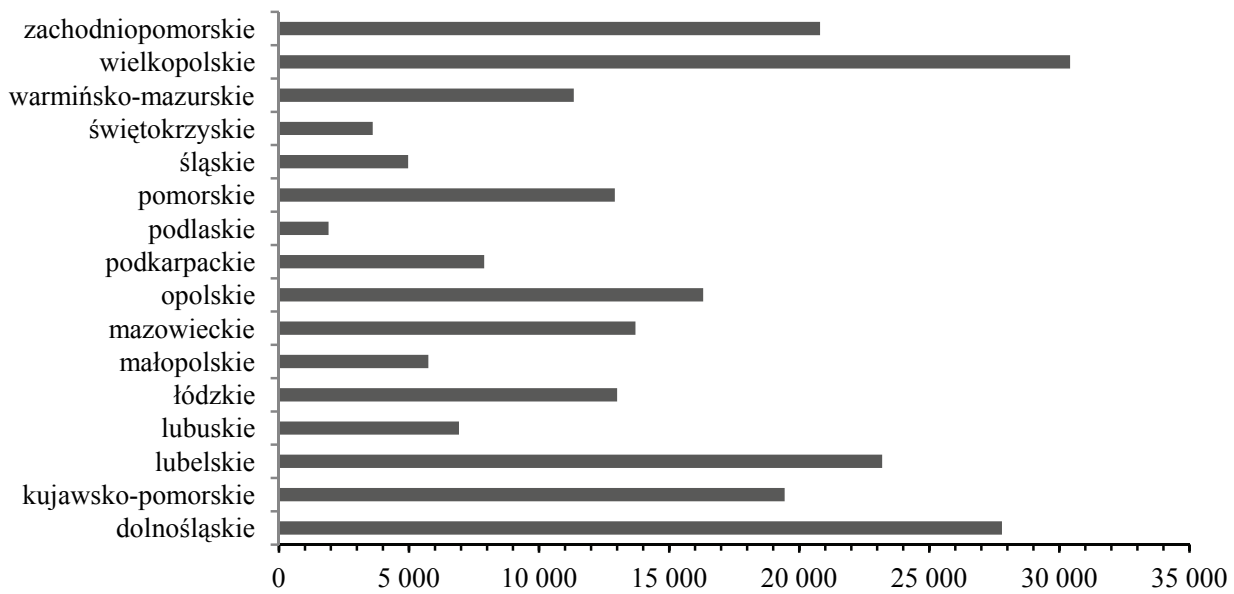

Rys. 2. Potencjał energetyczny słomy w województwach

Fig. 2. Energy potential of straw in voivodships

Źródło: opracowanie własne.

Jednym z kierunków pozyskania energii z biomasy jest bezpośrednie spalanie surowców. Słoma w postaci bel wykorzystywana jest głównie do produkcji energii cieplnej. Jednak spalanie słomy budzi coraz więcej kontrowersji. Zwolennicy podkreślają szczególne korzyści środowiskowe współspalania lub spalania biomasy zamiast węgla kamiennego (Dzikuć, 2014). Uważa się, że $\mathrm{CO}_{2}$ emitowany przy spalaniu biomasy został uprzednio zasymilowany przez rośliny w procesie fotosyntezy. W opozycji istnieje pogląd, że podczas spalania biomasy emisja $\mathrm{CO}_{2}$ wcale nie jest zerowa, a nadwyżki słomy należy przeznaczać na przyoranie zwiększając sekwestrację węgla organicznego (Wójcicki, 2015). Należy podkreślić, że duży udział zbóż w strukturze zasiewów generuje konieczność ich uprawy w uproszczonych zmianowaniach, a często w monokulturze. Uprawa zbóż w monokulturze i wieloletnie przyorywanie słomy zubażają różnorodność materii organicznej (wzrasta zagęszczenie gleby, obniżeniu ulega $\mathrm{pH}$, pogarsza się struktura gleby). Częste przyorywanie słomy potęguje także występowanie chorób.

Istotnym źródłem energii odnawialnej może być biomasa $\mathrm{z}$ trwałych użytków zielonych. $\mathrm{W}$ ostatnim czasie TUZ utraciły prymat $\mathrm{w}$ produkcji pasz dla przeżuwaczy. Zmniejszenie opłacalności chowu zwierząt przeżuwających, zmiany zasad żywienia zmniejszyły zapotrzebowanie na paszę pastwiskową oraz siano i kiszonkę $\mathrm{z}$ trwałych użytków zielonych (Terlikowski, 2012). Ograniczony stopień wykorzystania TUZ powoduje szkody przyrodnicze (degradacja gleb i roślinności) oraz straty ekonomiczne (niewykorzystany potencjał produkcyjny ląk i pastwisk), zatem część tej biomasy może być wykorzystana do celów energetycznych.

Trwałe użytki zielone w 2010 roku zajmowały 3281,7 tys. ha, w tym 2628,6 tys. ha stanowiły łąki $(80,1 \%$ TUZ) i 653,1 tys. ha pastwiska $(19,9 \%)$. W 2015 r. powierzchnia łąk utrzymała się na poziomie 2658,1 tys. ha, natomiast spadła powierzchnia pastwisk, osiaggając areał 434,7 tys. ha. Przeprowadzona analiza wykazała, że w 2015 r. z trwałych użytków zielonych można zebrać w skali kraju ponad 13 902,5 tys. ton biomasy. Po 
odliczeniu zapotrzebowania na pasze objętościowe dla bydła, oszacowana na 3078,3 tys. ton biomasa może stanowić źródło energii odnawialnej. Przewidywany zbiór siana pozwala na wyprodukowanie 41249 TJ energii cieplnej i może zastapić 1719 tys. ton węgla o średniej wartości opałowej. Analizując potencjał energetyczny biomasy z trwałych użytków zielonych można zauważyć, że największym potencjałem charakteryzują się gminy położone na terenie południowej, zachodniej i częściowo wschodniej części kraju (rys. 3).

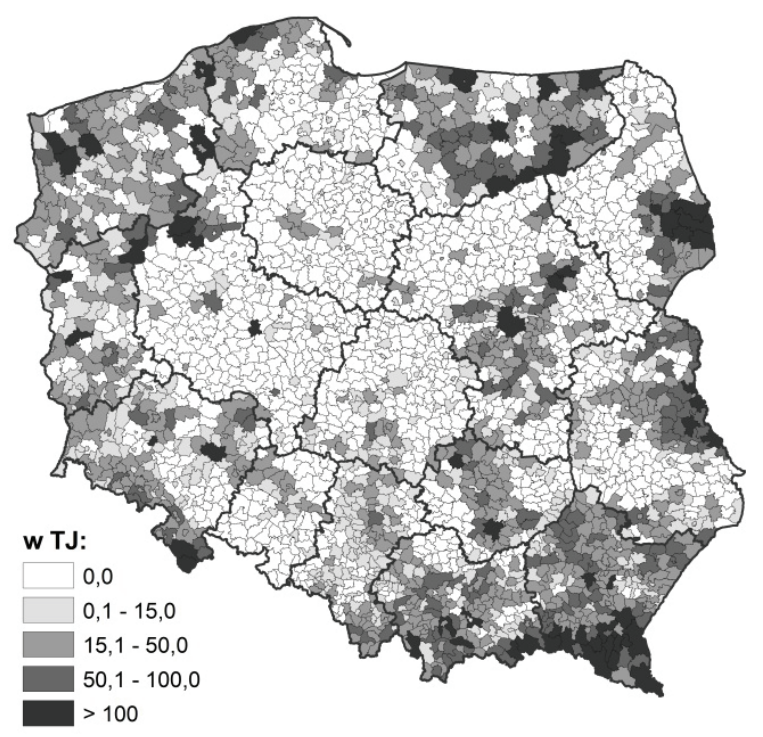

Rys. 3. Potencjał energetyczny siana

Fig. 3. Energy potential of hay

Źródło: opracowanie własne.

Największymi zasobami siana cechują się województwa: podkarpackie - 7354,4 $\mathrm{TJ} /$ rok i małopolskie - 4 778,0 TJ/rok (rys. 4). Natomiast najmniejszym potencjałem energetycznym zasobów $\mathrm{z}$ trwałych użytków zielonych charakteryzuje się województwo kujawsko-pomorskie - 196,1 TJ/rok, opolskie $-289,5 \mathrm{TJ} /$ rok i łódzkie $-644,2 \mathrm{TJ} /$ rok. Jak sugerują Mikołajczak i in. (2009) najlepszym wykorzystaniem tej biomasy jest przeznaczenie do produkcji biogazu w formie sianokiszonki. Zakładając, że z 1 tony biomasy trawiastej można uzyskać około $500 \mathrm{~m}^{3}$ biogazu, można wyprodukować ponad 1,5 mld $\mathrm{m}^{3}$ biogazu rocznie. Biogaz wytwarzany $\mathrm{z}$ biomasy rolniczej może stanowić ważne źródło zaopatrzenia w energię elektryczną i cieplną. Można zatem uzyskać tanią energię i przyczyniać się do ochrony TUZ przed degradacją. Jednak ze względu na dużą zmienność warunków siedliskowych wpływających na wielkość plonowania oraz zmienność przestrzenną trwałych użytków zielonych, biomasa ta powinna być wykorzystywana regionalnie w małych biogazowniach rolniczych. 


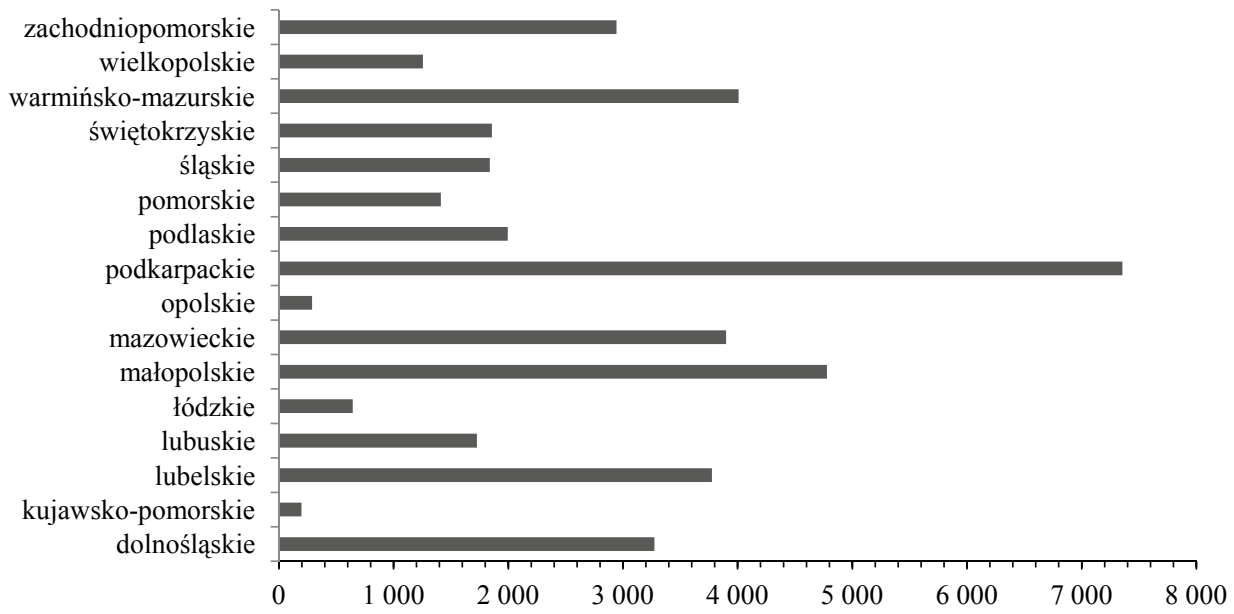

Rys. 4. Potencjał energetyczny siana w województwach

Fig. 4. Energy potential of hay in voivodships

Źródło: opracowanie własne.

Rosnące zapotrzebowanie na biomasę wywołało zainteresowanie tzw. wieloletnimi plantacjami energetycznymi, które w relatywnie krótkim okresie uzyskują duże przyrosty biomasy. Wieloletnie rośliny energetyczne charakteryzują się lepszymi właściwościami energetycznymi. Całkowita powierzchnia upraw wieloletnich roślin energetycznych w 2010 r. wynosiła 8114,8 ha, a potencjał energetyczny istniejących plantacji oszacowano na 1269,2 TJ. Oszacowany potencjał biomasy pochodził głownie z wieloletnich plantacji wierzby, miskanta i ślazowca pensylwańskiego.

Dla osiąnnięcia wyznaczonego celu ilościowego zwartego w Dyrektywie 2009/28/WE konieczne będzie zakładanie nowych plantacji roślin energetycznych. Wiele gatunków roślin wieloletnich można polecić do uprawy na cele energetyczne. Możliwość ich uprawy zależy od warunków siedliskowych. Duże przestrzenne zróżnicowanie warunków przyrodniczych, w tym głównie glebowych, wodnych i klimatycznych, stanowi znaczne ograniczenie w wyborze lokalizacji plantacji roślin energetycznych. Dlatego też zidentyfikowano obszary spełniające wymagania dla uprawy wieloletnich roślin energetycznych i dokonano przestrzennej delimitacji gruntów najbardziej odpowiednich do ich uprawy. W analizach założono, że wieloletnie rośliny energetyczne powinny być uprawiane poza obszarami chronionymi i górskimi, w rejonach o rocznej sumie opadów większej niż $550 \mathrm{~mm}$ i na glebach gorszej jakości, mniej przydatnych do produkcji żywności (Jadczyszyn i in., 2008). Z możliwej do wykorzystania na cele energetyczne powierzchni oszacowano potencjał energetyczny $\mathrm{z}$ teoretycznych plantacji roślin energetycznych, który wyniósł 43 305,6 TJ. Łączny potencjał energetyczny z upraw wieloletnich dla Polski oszacowano na poziomie 44,6 tys. TJ rocznie (rys. 5). Regionami o najwyższym potencjale okazały się województwa: mazowieckie - 5225,7 TJ/rok, zachodniopomorskie - 4 486,6 TJ/rok, podlaskie - $4224,4 \mathrm{TJ} /$ rok, łódzkie $-4085,6$ $\mathrm{TJ} /$ rok, dolnośląskie - $3556,7 \mathrm{TJ} /$ rok i lubelskie - 3509,6 TJ/rok. Najmniejszym zaś 
potencjałem charakteryzowały się województwa: kujawsko-pomorskie - 428,4 TJ/rok, małopolskie - 890,1 TJ/rok i świętokrzyskie - 1 083,7 TJ/rok.

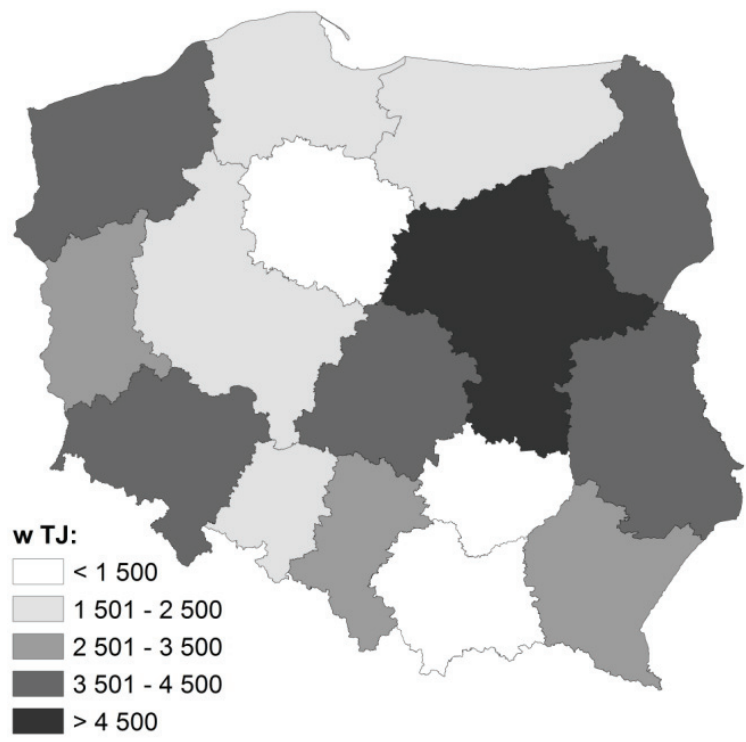

Rys. 5. Potencjał energetyczny wieloletnich roślin energetycznych

Fig. 5. Energy potential of perennial energy crops

Źródło: opracowanie własne na podstawie Jadczyszyn i in. (2008).

Polska dysponuje dużym potencjałem analizowanej biomasy roślinnej. Całkowity oszacowany potencjał wyniósł 305,8 tys. TJ (rys. 6). Największym potencjałem cechują się województwa zachodniej Polski (dolnośląskie - 34,6 tys. TJ/rok i wielkopolskie - 33,9 tys. $\mathrm{TJ} /$ rok). Do regionów o wysokim potencjale energetycznym należy zaliczyć także województwa: lubelskie $-30,5$ tys. TJ/rok, zachodniopomorskie $-28,2$ tys. TJ/rok, mazowieckie $-22,8$ tys. TJ/rok i kujawsko-pomorskie $-20,1$ tys. TJ/rok. Najmniejszy potencjał energetyczny biomasy roślinnej stwierdzono w województwie świętokrzyskim 6,5 tys. $\mathrm{TJ} / \mathrm{rok}$

Należy jednak zwrócić uwagę, że w oszacowanym potencjale biomasy roślinnej z produkcji rolnej została uwzględniona teoretyczna biomasa $\mathrm{z}$ wieloletnich roślin energetycznych możliwa do uzyskania $\mathrm{z}$ powierzchni dedykowanych do ich uprawy. Realnie biomasa lignino-celulozowa produkowana jest na niewielkiej powierzchni, a miała stanowić jedno z głównych źródeł energii odnawialnej dla energetyki. Jednak powierzchnia tych upraw zarówno w Unii Europejskiej, jak i w Polsce nie rośnie. Powodem takiej sytuacji są wysokie koszty zakładania plantacji oraz brak systemu kontraktacji zapewniającego opłacalność produkcji. Zachętą do zakładania nowych plantacji może być promowanie partnerskich rozwiązań zmierzających do tworzenia baz surowcowych przez wszystkich zainteresowanych użytkowników, gwarantujące odbiór surowca na ustalonych warunkach. 


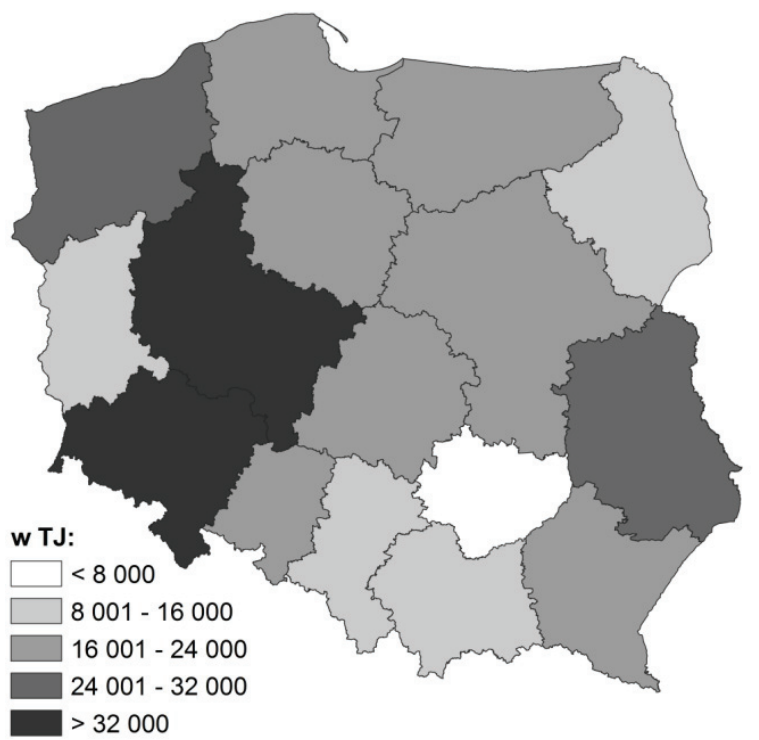

Rys. 6. Całkowity potencjał energetyczny biomasy roślinnej

Fig. 6. Total energy potential of crops biomass

Źródło: opracowanie własne.

Biomasa jest obecnie zużywana przez gospodarstwa w celach grzewczych oraz spalana przez energetykę zawodową. Największe korzyści ekonomiczne i ekologiczne można uzyskać wykorzystując biomasę najbliżej miejsc, w których jest wytwarzana (DudaKękuś, 2011). Ze względu na ekonomikę transportu, jak sugerują Faber i in. (2009), 50\% biomasy powinno być pozyskiwane przez energetykę zawodową, a pozostała część wykorzystywana lokalnie.

Jak wspomniano, zgodnie z dyrektywą 2009/28/WE państwa członkowskie sa zobowiązane do zapewnienia określonego udziału energii ze źródeł odnawialnych w końcowym zużyciu energii brutto w 2020 r. „Polityka energetyczna Polski do 2030 roku” - dokument zawierający strategiczne rozwiązania $\mathrm{w}$ dziedzinie polskiej energetyki, wskazuje do 2030 r. stopniowy wzrost zapotrzebowania na energię finalną brutto $\mathrm{z}$ odnawialnych źródeł energii (tab. 1). Przewiduje się, że w 2020 r. udział zużycia biomasy stałej $\mathrm{w}$ produkcji energii elektrycznej wyniesie $33,2 \%$, a w produkcji ciepła $86,4 \%$. Oczekuje się, że łączne prognozowane zapotrzebowanie biomasy stałej na potrzeby energetyki wyniesie 263,7 PJ. Tak więc, wykorzystanie oszacowanego potencjału biomasy roślinnej mogłoby w pełni pokryć przewidywane na 2020 r. zapotrzebowanie. Pozyskanie tej biomasy nie konkuruje z produkcją na cele żywnościowe. 
Tabela 1. Zapotrzebowanie na energię finalną brutto $\mathrm{z}$ odnawialnych źródeł energii (w PJ)

Table 1. Demand for gross final energy from renewable energy sources (in PJ)

\begin{tabular}{l|ccccc}
\hline \multicolumn{1}{c|}{ Wyszczególnienie } & 2010 & 2015 & 2020 & 2025 & 2030 \\
\hline Energia elektryczna & 29,9 & 63,5 & 112,5 & 136,3 & 142,2 \\
w tym biomasa stała & 12,5 & 21,7 & 37,4 & 39,9 & 41,6 \\
Ciepło & 187,6 & 211,2 & 261,9 & 295,1 & 318,9 \\
w tym biomasa stała & 180,6 & 192,4 & 226,3 & 245,8 & 265,1 \\
Biopaliwa transportowe & 23,0 & 37,0 & 60,5 & 68,3 & 78,8 \\
Energia finalna brutto & 2566,7 & 2678,2 & 2896,8 & 3159,6 & 3371,9 \\
Energia finalna brutto z OZE & 240,5 & 311,7 & 343,8 & 499,7 & 539,9 \\
\% udziału energii odnawialnej & 9,4 & 11,6 & 15,0 & 15,8 & 16,0 \\
\hline
\end{tabular}

Źródło: obliczenia własne na podstawie Krajowego planu działania (2010).

\section{Podsumowanie}

Wykorzystanie energii ze źródeł odnawialnych w krajach członkowskich reguluje Dyrektywa 2009/28/WE. Zarówno w Unii Europejskiej, jak i w Polsce notuje się systematyczny wzrost udziału energii odnawialnej $w$ pozyskaniu energii brutto. Podstawowym źródłem energii jest biomasa stała. W elektroenergetyce i ciepłownictwie jako biomasa użytkowa zastosowane mogą być produkty uboczne z produkcji roślinnej (słoma, siano) oraz wieloletnie rośliny energetyczne. Z przeprowadzonych badań wynika, że Polska dysponuje potencjałem biomasy roślinnej, kształtującym się na poziomie 305,8 tys. TJ rocznie, który może być wykorzystany do celów energetycznych bez uszczerbku dla produkcji żywności. Wykorzystanie tych zasobów może przynieść wymierne korzyści w postaci: dywersyfikacji źródeł energii, zwiększenia bezpieczeństwa energetycznego, poprawy stanu środowiska i wzrostu zatrudnienia.

\section{Literatura}

Duda-Kękuś, A. (2011). Transport biomasy w logistyce dostaw paliw dla elektrowni systemowych realizujących program zielonej energetyki, Logistyka, 2, 107-118.

Dyrektywa 2009/28/WE z dnia 23 kwietnia 2009 roku w sprawie promowania stosowania energii ze źródeł odnawialnych, Dz.U. UE L 09.140.16. Pobrane 15 stycznia 2016 z: https://www.ure.gov.pl/pl/prawo/prawowspolnotowe/dyrektywy/4925,DzU-UE-L-0914016.html.

Dzikuć, M. (2014). Znaczenie wykorzystania współspalania biomasy w produkcji energii elektrycznej w Polsce. Prace Naukowe Uniwersytetu Ekonomicznego we Wrocławiu, 361, 48-56.

Energia ze źródeł odnawialnych w 2015 r. (2016). Informacje i opracowania statystyczne. Warszawa.

Gradziuk, P. (red.). (2002). Biopaliwa, Wyd. "Wieś Jutra", Warszawa.

Gradziuk, P. (2015). Gospodarcze znaczenie i możliwości wykorzystania słomy na cele energetyczne. Monografie i Rozprawy Naukowe IUNG-PIB Puławy, 45, 1-173.

Faber, A., Kuś, J., Matyka, M. (red.). (2009). Uprawa roślin na potrzeby energetyki. W\&B Wiesław Drzewiński, Warszawa.

Grzybek, A., Gradziuk, P., Kowalczyk, K. (2002). Słoma- energetyczne paliwo. Wyd. „Wieś Jutra”, Warszawa.

GUS. (2011). Powszechny spis rolny 2010. Pobrane 25 marca 2013 z: http://stat.gov.pl/spisypowszechne/powszechny-spis-rolny-2010/.

Harasim, A. (2011). Gospodarowanie słomą, Puławy, IUNG, 77. 
Jadczyszn, J., Faber A., Zaliwski A. (2008). Wyznaczanie obszarów potencjalnie przydatnych do uprawy wierzby i ślazowca pensylwańskiego na cele energetyczne w Polsce. Studia i Raporty IUNG-PIB Puławy, 11, 55-65.

Jarosz, Z. (2016). Potencjał techniczny słomy w Polsce i efekty środowiskowe jej alternatywnego wykorzystania. Rocz. Nauk. SERiA, 18(1), 84-89.

Krajowy plan działania w zakresie energii ze źródeł odnawialnych. (2010). Minister Gospodarki. Warszawa, 1203.

Kuś, J., Faber, A. (2007). Alternatywne kierunki produkcji rolniczej. Studia i Raporty IUNG-PIB Puławy, 7, $138-158$.

Ludwicka, A., Grzybek, A. (2010). Bilans biomasy rolnej (słomy) na potrzeby energetyki. Probl. Inż. Rol., 2, 101-111.

Mikołajczyk, J., Wróbel, B., Jurkowski, A. (2009). Możliwości i bariery w produkcji biogazu z biomasy trwałych użytków zielonych w Polsce. Woda-Środowisko-Obszary Wiejskie, 2(26), 139-155.

Polityka energetyczna Polski do 2030 roku. (2009). Ministerstwo Gospodarki. Załącznik do uchwały nr 202/2009 Rady Ministrów z dnia 10 listopada 2009 r. Warszawa, 1-29.

RENEW. (2008). Residue biomass potential inventory results. Pobrane 15 marca 2013 z: http://www.renewfuel.com.

Scarlat, N., Martinov, M., Dallemand, J. F. (2010). Assessment of the availability of agricultural crop residues in the European Union: Potential and limitations for bioenergy use. Waste Management, 30, 1889-1897.

Terlikowski, J. (2012). Biomasa z trwałych użytków zielonych jako źródło energii odnawialnej. Probl. Inż. Rol., $1(75), 43-49$.

Winnicki, S., Jugowar, J. L., Nawrocki, L. (2012). Analiza możliwości organizacji bazy paszowej na glebach o niskiej bonitacji dla stada krów o wysokiej wydajności. Woda-Środowisko-Obszary Wiejskie, 1(37), 239248.

Wójcicki, Z. (2015). Znaczenie biomasy w energetyce i gospodarce żywnościowej. Probl. Inż. Rol., 1(87), 5-15. 